\title{
Performance of Hybrid Rice Cultivar (Oryza sativa L.) on Growth and Yield Attributes under Agro-Climatic Conditions of Allahabad Uttar Pradesh in Aman Season of Planting
}

\author{
Vikram Singh, Rachana, Prasad Mithare*, Sujit Kumar, J. P. Mishra, \\ Sachchida Nand Singh, Dhananjay Tiwari and Lalit Kumar Sanodiya \\ Department of Agronomy, Allahabad School of Agriculture, Sam Higginbottom University of \\ Agriculture Technology \& Sciences, Allahabad-211007, (Uttar Pradesh), India \\ *Corresponding author
}

\begin{abstract}
A B S T R A C T
Keywords

CGR, Days after

Transplanting

(DAT), Green

Revolution, Panicle

Initiation and RGR.

Article Info

Accepted:

25 August 2019

Available Online:

10 September 2019

The field experiment was conducted during Kharif season of 2016 at Crop Research Farm SHUATS, Allahabad (UP). The experiment was carried out to find the performance of 40 hybrids, which laid out in Randomized Block Design (RBD) \& replicated thrice. The experiment finding revealed that the treatment $\mathrm{T}_{38}$ (KR 38) has performed significantly better than all other hybrids viz; Germination (96\%), Plant height $(115.14 \mathrm{~cm})$, Number of tillers per $\mathrm{m}^{2}$ (381.00), Panicle length $(30.70 \mathrm{~cm})$, Number of filled grains plant ${ }^{-1}$ (307.66), Number of un-filled grains plant ${ }^{-1}$ (22.56), Test weight (29.89 g), Grain yield plant $^{-1}(0.041 \mathrm{~kg})$, Grain yield $\left(13.96 \mathrm{t} \mathrm{ha}^{-1}\right)$, Straw yield $\left(19.98 \mathrm{t} \mathrm{ha}^{-1}\right)$, Biological Yield (33.94 t ha-1). While the same treatment $\mathrm{T}_{38}$ (KR 38) recorded highest gross return, net return and $\mathrm{B}$ : $\mathrm{C}$ ratio However treatment $\mathrm{T}_{35}(\mathrm{KR} 35)$, $\mathrm{T}_{25}$ (KR 25), $\mathrm{T}_{36}(\mathrm{KR} 36)$ and $\mathrm{T}_{16}(\mathrm{KR} 16)$ were statistically at par with treatment $\mathrm{T}_{38}(\mathrm{KR} 38)$ respectively.
\end{abstract}

\section{Introduction}

Cereals are the member of grasses, which belong to family Gramineae (Poaceae) and cultivated for edible components of their grain which is composed of the endosperm, germ and bran. Rice Oryza sativa L. $(2 \mathrm{n}=24)$ belongs to the family Gramineae (Poaceae). The genus Oryza contains 24 recognized species, of which 22 are wild species and two cultivated ( $O$. sativa and $O$. glaberrima). Rice is one of the three most important cereal food grain crop of the world and forms the staple diet of 2.7 billion people. Except Antarctica, it is grown in all the continents, occupying 159 million hectare area and producing 683 million tonnes FAO, 2011. India's share in the world rice production is $21.6 \%$. India holds second and China holds the first position in rice production in the world FAO, 2011. Our 
rice requirement by the year 2020 is estimated to be around 122 million tons as against the present production of about 100 million tons, thus leaving a gap of about 22 million tons rice. Present production level needs to be increased up to 140 million tons by 2025 which can be achieved only by increasing the rice production by over 2 million tons per year incoming decade Anonymous 2005. The rice accounts for about $43 \%$ of total food grain production and $46 \%$ of total cereal production in the country Anonymous 2006. Rice is the only crop which providing major source of the food energy for more than half of the human population. More than 90 per cent of the world's rice is produced and consumed in Asia, where it is an integral part of culture and tradition. Rice occupies a pivotal place in Indian agriculture and it is contributes to 15 per cent of annual GDP and provides 43 per cent calorie requirement for more than 70 per cent of Indians. Around $65 \%$ of the total population in India depends on rice and it accounts for $40 \%$ of their food production Anonymous 2005. India has 365.69 lakh hectare area is under rice cultivation in kharif 2019. Highest area under rice cultivation is reported from the state of Madhya Pradesh (3.50 lakh $\mathrm{ha}^{-1}$ ) followed by Telangana (3.49 lakh $\left.\mathrm{ha}^{-1}\right)$, while lowest area under rice cultivation was reported in Uttarakhand $(0.01$ lakh $\left.\mathrm{ha}^{-1}\right)$. The second estimate rice production (115.60) million tonnes in the year 2018-19 GOI 2019. Whereas highest average productivity of rice was $2550 \mathrm{~kg} \mathrm{ha}^{-1}$ during 2016-17 respectively GOI 2017. Rice is the staple food for 50-60\% of the global population and its demand continues to grow Carriger and Vallee 2007, Mohanty et al., 2013 and Stoop et al., 2009. Rice is rich source of carbohydrates (calories) which contain less protein compared to wheat. The protein content of milled rice is usually (6$7 \%$ ). However, rice contains favorable amino acid which is higher as compared with other cereals in amino acids content. The biological value of its protein is high and fat content of rice is low (2.0 to $2.5 \%$ ) and much of the fat is lost during milling. It is estimated that 5000 liters of water is needed to produce $1 \mathrm{~kg}$ of Rice Bouman et al., 2009. Rice production and productivity was significantly enhanced with the introduction and cultivation of semidwarf, fertilizer responsive and non-lodging high yielding varieties in the early seventies leading to the "Green Revolution". Hybrid rice technology has provided farmers with high yields, saved land for agricultural diversification and created rural employment opportunities. The demand of quality hybrid rice seeds is increasing day by day. This can be achieved only through identification of high yielding rice hybrids and participatory programme of researchers, farmers, NGO's, seed growers and farmers should be involved in it for increased production and productivity of hybrid rice.

\section{Materials and Methods}

A field experiment was conducted during kharif season of 2016 at the Crop Research farm, Department of Agronomy, Allahabad School of Agricultural, Sam Higginbottom University of Agriculture Technology and Sciences, Allahabad. The experiment site lies between $25-27^{\circ} \mathrm{N}$ latitude, $8.5^{\circ} \mathrm{E}$ Longitude and 98 meters altitude. The climate is characterized by the alternate hot rainy season from late June to early September with mean temperature of $38^{\circ} \mathrm{C}$. The soil was sandy loam in texture having a $\mathrm{pH}(7.2), \mathrm{EC}\left(0.14 \mathrm{dSm}^{-1}\right)$, organic carbon $(0.38 \%)$, available $\mathrm{N}(225 \mathrm{~kg}$ $\left.\mathrm{ha}^{-1}\right), \mathrm{P}\left(19.5 \mathrm{~kg} \mathrm{ha}^{-1}\right), \mathrm{K}$ (340 kg ha $\left.\mathrm{kg}^{-1}\right), \mathrm{S}$ (16.8.00 ppm), and $\mathrm{Zn}(0.51 \mathrm{ppm})$ during the experimental year. The experiment was laid down in randomized block design (RBD) with 40 treatments and 3 replications. Twenty five days old seedlings were transplanted to main field conventionally at a spacing of $20 \times 10$ $\mathrm{cm}$. The crop was fertilized with recommended dose of NPK 160:80:60 $\mathrm{kg} \mathrm{ha}^{-1}$ 
was applied. The (100\%) full dose phosphorus and potassium whereas (50\%) of Nitrogen was applied at the time of planting as basal dose and the remaining Nitrogen was applied in two equal split doses as top dressing at active (Tillering \& Panicle Initiation stage) respectively. Similarly $\mathrm{ZnSo}_{4}$ was applied as basal dose at the rate of $25 \mathrm{~kg} \mathrm{ha}^{-1}$ for correction of zinc and sulphur deficiency. Irrigation was scheduled at 10-12 days interval as flooding; however other normal cultural practices were followed timely as; weeding at 30 DAT \& 45 DAT. One quadrate $\left(1 \mathrm{~m}^{2}\right)$ was harvested in every plot for the determination of results and data was subjected to statistical analysis separately by using analysis of variance technique. The difference among treatment means was compared by using least significant difference test at $5 \%$ probability levels. The treatment consisted of Hybrids $\mathrm{T}_{1}$ : (KR 01), $\mathrm{T}_{2}$ : (KR 02), $\mathrm{T}_{3}$ : (KR 03), $\mathrm{T}_{4}:(\mathrm{KR}$ 04), $\mathrm{T}_{5}$ : (KR 05), $\mathrm{T}_{6}$ : (KR 06), $\mathrm{T}_{7}$ : (KR 07), $\mathrm{T}_{8}$ : (KR 08), $\mathrm{T}_{9}$ : (KR 09), $\mathrm{T}_{10}$ : (KR 10), $\mathrm{T}_{11}$ : (KR 11), $\mathrm{T}_{12}:(\mathrm{KR} 12), \mathrm{T}_{13}:(\mathrm{KR} 13), \mathrm{T}_{14}:(\mathrm{KR}$ 14), $\mathrm{T}_{15}:(\mathrm{KR} 15), \mathrm{T}_{16}:(\mathrm{KR} 16), \mathrm{T}_{17}:(\mathrm{KR} 17)$, $\mathrm{T}_{18}$ : (KR 18), $\mathrm{T}_{19}:(\mathrm{KR} 19), \mathrm{T}_{20}:(\mathrm{KR} 20), \mathrm{T}_{21}$ : (KR 21), T22: (KR 22), T23: (KR 23), T24: (KR 24), $\mathrm{T}_{25}$ : (KR 25), $\mathrm{T}_{26}$ : (KR 26), $\mathrm{T}_{27}$ : (KR 27), $\mathrm{T}_{28}$ : (KR 28), $\mathrm{T}_{29}$ : (KR 29), $\mathrm{T}_{30}$ : (KR 30), $\mathrm{T}_{31}$ : (KR 31), T32: (KR 32), T33: (KR 33), T34: (KR 34), $\mathrm{T}_{35}$ : (KR 35), $\mathrm{T}_{36}:(\mathrm{KR} 36), \mathrm{T}_{37}:(\mathrm{KR} 37)$, $\mathrm{T}_{38}$ : (KR 38), $\mathrm{T}_{39}$ : (KR 39), $\mathrm{T}_{40}$ : (KR 40).

\section{Results and Discussion}

\section{Growth Attributes}

\section{Germination (\%)}

The germination percentage is not a yield component in field crops but it indicates the influence of various enzymatic changes in the seed and its embryo. Germination percentage in laboratory was done with various hybrids, the highest germination percentage $(96 \%)$ was recorded in $\mathrm{T}_{38}$ (KR-38) and lowest germination percentage $(64 \%)$ was recorded in treatment $\mathrm{T}_{26}(\mathrm{KR}-26)$ as shown in (Table 1 and Fig 1) respectively.

\section{Plant height (cm)}

Plant height is not a yield component especially in grain crops but it indicates the influence of various essential plant nutrients on plant metabolism. Significantly maximum plant height $(115.14 \mathrm{~cm})$ was recorded in treatment $\mathrm{T}_{38}$ (KR 38) followed by (114.08 $\mathrm{cm})$ in treatment $\mathrm{T}_{23}(\mathrm{KR}-23)$ and minimum plant height $(88.22 \mathrm{~cm})$ was recorded in treatment $\mathrm{T}_{10}(\mathrm{KR} 10)$ at 80 DAT. However treatment $\mathrm{T}_{8}, \mathrm{~T}_{21}, \mathrm{~T}_{37}, \mathrm{~T}_{20}, \mathrm{~T}_{30}$ and $\mathrm{T}_{26}$ were statistically at par with treatment $\mathrm{T}_{38}$ (KR 38) as shown in (Table 1 and Fig 1) respectively. The increased plant height might be due to genetic makeup like genetic character and genetic disparity of the cultivar. This may be due to first generation hybrid vigor of the plant compared to other cultivars Paramasivan et al., 1988. Increase in plant height may also be due to synchronized availability of all the essential plants nutrients to the crop especially nitrogen for a longer period during its growth stages Deshpande \& Devasenpathy 2011 and Haque et al., 2015. Similar finding are also confirmed by Parihar et al., 2005, Kalyani et al., 2012 and Kumar et al., 2015.

\section{Plant dry weight (g)}

The observations regarding plant dry weight were recorded at different intervals 20, 40, 60 and 80 DAT was found non-significant difference among the treatments. However maximum plant dry weight (41.87 g) was observed in treatment $\mathrm{T}_{38}(\mathrm{KR} 38)$ and minimum plant dry weight $(31.60 \mathrm{~g})$ was recorded in treatment $\mathrm{T}_{10}(\mathrm{KR} 10)$ at 80 DAT. The increase in plant dry weight $(\mathrm{g})$ in various hybrids might be due to more assimilatory surface leading to higher dry matter production coupled with effective 
translocation and distribution of photosynthates from source to sink. Dry matter accumulation depends upon the photosynthesis and respiration rate during vegetative growth; hybrid rice accumulates more dry matter in the early and middle growth stages which results in more spikelets per panicle. The hybrids variety (KR 38) has bigger panicles and more spikelet's panicle ${ }^{-1}$. These factors result in higher yields usually 15 $\%$ or more than ordinary rice Philrice et al., 2002. Similar findings are also confirmed by Singh and Khan 2003.

\section{Crop Growth Rate (g $\left.\mathrm{m}^{-2} \mathrm{day}^{-1}\right)$ and Relative Growth Rate $\left(\mathrm{g} \mathrm{g}^{-1}\right.$ day $\left.^{-1}\right)$}

Crop growth rate $\left(\mathrm{g} \mathrm{m}^{-2}\right.$ day $\left.^{-1}\right)$ of hybrid rice was recorded at different intervals 0-20, 2040, 40-60 and 60-80 DAT was found nonsignificant difference among the treatments. Similarly Relative growth rate $\left(\mathrm{g} \mathrm{g}^{-1}\right.$ day $\left.^{-1}\right)$ of hybrid rice was recorded at different intervals 20-40, 40-60 and 60-80 DAT was found nonsignificant difference among the treatments. However maximum CGR (55.82) and RGR $(0.065)$ were recorded in treatment $\mathrm{T}_{38}(\mathrm{KR}$ 38 ) at 40-60 DAT, while minimum CGR (35.47) and RGR (0.034) was recorded in treatment $\mathrm{T}_{10}$ (KR 10) respectively. The percentage decrease in CGR and RGR in various hybrids and showing non-significant difference among the treatment is due to prevalence of low temperature coupled with less humidity at the growth and reproductive stage especially during flag leaf stage. Similar findings are also reported by Yadav et al., 2004.

\section{Number of Tillers per $\mathbf{m}^{2}$}

No. of tillers per $\mathrm{m}^{2}$ is technically a growth parameter but scientifically it play an major role yield component especially in cereal crops but it indicates the influence of various essential plant nutrients on plant physiology and metabolism involved in the plant. Significantly higher No. of tillers per $\mathrm{m}^{2}$ (381.00) was recorded in treatment $\mathrm{T}_{38}(\mathrm{KR}$ 38) followed by (380.66) in treatment $T_{2}$ (KR$02)$, while lowest No. of tillers per $\mathrm{m}^{2}$ (222.90) was recorded in treatment $\mathrm{T}_{37}(\mathrm{KR}$ 37). However treatment $\mathrm{T}_{40}, \mathrm{~T}_{30}, \mathrm{~T}_{9}, \mathrm{~T}_{14}, \mathrm{~T}_{36}$ and $\mathrm{T}_{32}$ were statistically at par with treatment $\mathrm{T}_{38}$ (KR 38) as shown in (Table 1 and Fig 1) respectively.

The number of tillers are significantly influenced by genetic potential of the variety and also may be due to synchronized availability of essential plants nutrients to the crop especially NPK for a longer period during its growth \& reproductive stages. Increased number of effective tillers hill ${ }^{-1}$ may have helped in increasing the photosynthetic area for photosynthesis in plant. In several rice cultivars, the effect on number of effective tillers production at all the growth stages was significant, the number increased till 77 DAT followed by a decline to harvest due to death of some undeveloped tillers, thus tillers development was found to be more in hybrid varieties apart from local variety reported by Akram et al., 2007. Similarly significant differences could be attributed to the fact that high yielding hybrids have relatively high tillering capacity has been reported by Yadav et al., 2010.

\section{Number of Tillers hill ${ }^{-1}$}

The observations regarding No. of tillers hill ${ }^{-1}$ was found non-significant difference among the treatments. However higher No. of tillers hill $^{-1}$ (14.33) was observed in treatment $\mathrm{T}_{25}$ (KR 25) and lower No. of tillers hill ${ }^{-1}$ (8.33) was recorded in treatment $\mathrm{T}_{20}(\mathrm{KR} 20)$ as shown in (Table 1 and Fig 1) respectively.

\section{Panicle Length $(\mathrm{cm})$}

The longest panicle length $(30.70 \mathrm{~cm})$ was recorded in $\mathrm{T}_{38}$ (KR 38) followed by (30.167 
$\mathrm{cm})$ in treatment $\mathrm{T}_{14}(\mathrm{KR}-14)$ and shortest panicle length $(24.56 \mathrm{~cm})$ was recorded in treatment $\mathrm{T}_{3}$ (KR 03). However treatment $\mathrm{T}_{19}$ and $\mathrm{T}_{40}$ are statistically at par with treatment $\mathrm{T}_{38}$ (KR 38) as shown in (Table 2 and Fig 2) respectively. The longer panicles obtained in treatments might be the genetic potential of the hybrid and also may be due to synchronized availability of essential plants nutrients to the crop especially NPK for a longer period during its growth stages. The reason also might be due to better nutrients uptake by the cultivar during panicle growth period Sharma et al., 2014. Similar findings are confirmed by Rahman et al., 2013.

\section{Days to $50 \%$ Flowering}

Maximum days to $50 \%$ flowering (87.66 days) was recorded in $\mathrm{T}_{18}$ (KR 18) followed by $\left(86.33\right.$ and 85.66 days in Treatment $\mathrm{T}_{9}(\mathrm{KR}$ 09 ) and $\mathrm{T}_{17}$ (KR 17). While minimum days to $50 \%$ flowering (54.33 days) was recorded in treatment $\mathrm{T}_{6}(\mathrm{KR} 06)$ as shown in (Table 2 and Fig 2) respectively. Crop matures around 30 days of $50 \%$ flowering. However, the other reason might be due to the inherent characteristic of the cultivar to take minimum days to $50 \%$ flowering. The heritability is a measure of extent of phenotypic variation caused by the action of genes. In this experimental study, high heritability was observed for traits viz days to $50 \%$ flowering and days to maturity Haque et al., 2015 respectively.

\section{Days to Maturity}

Maximum days to maturity (116.33 days) was recorded in $\mathrm{T}_{17}$ (KR 17) followed by (108.67, 108.33 and 107.00 days) in Treatment $\mathrm{T}_{15}$ (KR 15), $\mathrm{T}_{18}$ (KR 18) and $\mathrm{T}_{21}$ (KR 21). While minimum days to maturity (68.67 days) was recorded in treatment $T_{13}$ (KR 13) as shown in
(Table 2 and Fig 2) respectively. Probably heritability is a measure of extent of phenotypic variation caused by the action of genes Haque et al., 2015. Prevalence of low temperature coupled with less humidity at flag leaf stage which might be reduced in duration and availability of ample supply of nutrients especially nitrogen through foliar feeding may be the reason for the better performance with regard to number of days to maturity Yadav et al., 2004.

\section{Yield Attributes}

\section{Number of filled grains plant ${ }^{-1}$}

Highest number of filled grains plant $^{-1}$ (307.66) was observed in treatment $\mathrm{T}_{38}$ (KR 38) followed by (269.66 and 261.33) in Treatment $\mathrm{T}_{6}$ (KR 06) and $\mathrm{T}_{33}$ (KR 33). While lowest number of filled grains plant ${ }^{-1}(189.00)$ was observed in Treatment $\mathrm{T}_{12}(\mathrm{KR} 12)$ as shown in (Table 3 ) and (Fig 3) respectively.

\section{Number of un-filled grains plant ${ }^{-1}$}

Lowest number of un-filled grains plant $^{-1}$ (22.56) was observed in treatment $\mathrm{T}_{38}$ (KR 38) followed by $(23.33,23.66,24.33$ and 25.66$)$ in Treatment $\mathrm{T}_{10}$ (KR 10), $\mathrm{T}_{4}$ (KR 04), $\mathrm{T}_{12}$ (KR 12 ) and $T_{19}$ (KR 19). While highest number of un-filled grains plant ${ }^{-1}$ (85.66) was observed in Treatment $\mathrm{T}_{16}$ (KR 16) as shown in (Table 3) and (Fig 3) respectively.

\section{Grain yield plant ${ }^{-1}$}

The highest grain yield plant ${ }^{-1}(41 \mathrm{~g})$ was observed in treatment $\mathrm{T}_{38}$ (KR 38) followed by $\left(40,36\right.$ and $36 \mathrm{~g}$ ) in Treatment $\mathrm{T}_{35}$ (KR 35), $\mathrm{T}_{5}$ (KR 05) and $\mathrm{T}_{29}$ (KR 29). While lowest grain yield plant ${ }^{-1}(22 \mathrm{~g})$ was observed in Treatment $\mathrm{T}_{18}$ (KR 18) as shown in (Table 3 ) and (Fig 3) respectively. 
Table.1 Performance of Hybrid Rice Cultivar (Oryza Sativa L.) on Growth Attributes viz, Germination (\%), Plant height (cm), Number of tiller per $\mathrm{m}^{2}$ and Number of tiller hill ${ }^{-1}$.

\begin{tabular}{|c|c|c|c|c|c|}
\hline & $\begin{array}{c}\text { Treatments Details } \\
\text { (Hybrids) }\end{array}$ & $\begin{array}{c}\text { Germination \% (in } \\
\text { laboratory) }\end{array}$ & $\begin{array}{l}\text { Plant height } \\
\text { (cm) }\end{array}$ & $\begin{array}{l}\text { No. of tiller per } \\
\mathbf{m}^{2}\end{array}$ & $\begin{array}{l}\text { No. of tiller } \\
\text { hill }^{-1}\end{array}$ \\
\hline $\mathbf{T}_{1}$ & KR-01 & 80 & 96.40 & 321.73 & 11.067 \\
\hline $\mathbf{T}_{2}$ & KR-02 & 88 & 93.31 & 380.66 & 9.733 \\
\hline $\mathbf{T}_{3}$ & KR-03 & 92 & 103.60 & 353.25 & 9.933 \\
\hline $\mathbf{T}_{4}$ & KR-04 & 94 & 100.37 & 352.80 & 10.867 \\
\hline $\mathbf{T}_{5}$ & KR-05 & 94 & 98.98 & 353.25 & 10.533 \\
\hline $\mathbf{T}_{6}$ & KR-06 & 94 & 99.29 & 325.33 & 9.933 \\
\hline $\mathbf{T}_{7}$ & KR-07 & 94 & 103.89 & 337.00 & 10.667 \\
\hline $\mathbf{T}_{8}$ & KR-08 & 94 & 112.94 & 293.33 & 9.533 \\
\hline $\mathbf{T}_{9}$ & KR-09 & 80 & 91.63 & 372.00 & 9.667 \\
\hline$T_{10}$ & KR-10 & 92 & 88.22 & 281.06 & 11.000 \\
\hline $\mathbf{T}_{11}$ & KR-11 & 94 & 103.86 & 285.33 & 10.400 \\
\hline $\mathbf{T}_{12}$ & KR-12 & 94 & 101.40 & 334.33 & 10.867 \\
\hline $\mathbf{T}_{13}$ & KR-13 & 80 & 95.51 & 246.40 & 9.133 \\
\hline$T_{14}$ & KR-14 & 92 & 97.90 & 369.27 & 11.000 \\
\hline $\mathbf{T}_{15}$ & KR-15 & 93 & 98.40 & 337.66 & 9.867 \\
\hline $\mathbf{T}_{16}$ & KR-16 & 94 & 102.33 & 258.93 & 13.467 \\
\hline $\mathbf{T}_{17}$ & KR-17 & 93 & 96.46 & 367.33 & 10.067 \\
\hline$T_{18}$ & KR-18 & 80 & 97.01 & 258.66 & 10.400 \\
\hline$T_{19}$ & KR-19 & 84 & 92.06 & 320.66 & 10.533 \\
\hline $\mathbf{T}_{20}$ & KR-20 & 76 & 107.04 & 289.66 & 8.333 \\
\hline $\mathbf{T}_{21}$ & KR-21 & 93 & 110.08 & 340.66 & 10.667 \\
\hline $\mathbf{T}_{22}$ & KR-22 & 94 & 104.38 & 338.66 & 12.667 \\
\hline $\mathbf{T}_{23}$ & KR-23 & 94 & 114.08 & 277.40 & 9.200 \\
\hline $\mathbf{T}_{24}$ & KR-24 & 92 & 102.35 & 267.80 & 14.333 \\
\hline $\mathbf{T}_{25}$ & KR-25 & 94 & 94.49 & 276.20 & 9.467 \\
\hline$T_{26}$ & KR-26 & 64 & 105.26 & 306.66 & 10.933 \\
\hline $\mathbf{T}_{27}$ & KR-27 & 95 & 100.61 & 248.26 & 9.667 \\
\hline $\mathbf{T}_{28}$ & KR-28 & 84 & 101.96 & 283.00 & 9.800 \\
\hline$T_{29}$ & KR-29 & 94 & 99.17 & 248.33 & 10.600 \\
\hline$T_{30}$ & KR-30 & 80 & 107.69 & 374.40 & 10.533 \\
\hline$T_{31}$ & KR-31 & 94 & 96.80 & 290.86 & 12.200 \\
\hline $\mathbf{T}_{32}$ & KR-32 & 68 & 99.94 & 360.00 & 11.833 \\
\hline $\mathbf{T}_{33}$ & KR-33 & 94 & 103.16 & 316.00 & 11.667 \\
\hline $\mathbf{T}_{34}$ & KR-34 & 80 & 88.97 & 306.53 & 8.733 \\
\hline$T_{35}$ & KR-35 & 95 & 98.70 & 242.80 & 9.400 \\
\hline $\mathbf{T}_{36}$ & KR-36 & 94 & 97.74 & 362.26 & 9.467 \\
\hline $\mathbf{T}_{37}$ & KR-37 & 88 & 109.27 & 222.90 & 8.533 \\
\hline $\mathbf{T}_{38}$ & KR-38 & 96 & 115.14 & 381.00 & 10.133 \\
\hline$T_{39}$ & KR-39 & 68 & 92.62 & 273.80 & 10.933 \\
\hline $\mathbf{T}_{40}$ & KR-40 & 88 & 103.41 & 377.60 & 10.267 \\
\hline \multicolumn{2}{|r|}{ F-test } & -- & $\mathbf{S}$ & S & NS \\
\hline \multicolumn{2}{|r|}{ S.Ed (+) } & -- & 5.37 & 48.01 & 1.57 \\
\hline \multicolumn{2}{|r|}{ C.D. $(P=0.05)$} & -- & 10.72 & 95.76 & -- \\
\hline
\end{tabular}


Table.2 Performance of Hybrid Rice Cultivar (Oryza Sativa L.) on Growth Attributes viz, Panicle length $(\mathrm{cm})$, Day to $50(\%)$ flowering and No. of days to maturity

\begin{tabular}{|c|c|c|c|c|}
\hline & $\begin{array}{c}\text { Treatments } \\
\text { Details (Hybrids) }\end{array}$ & $\begin{array}{c}\text { Panicle length } \\
(\mathrm{cm})\end{array}$ & $\begin{array}{l}\text { Day to } 50(\%) \\
\text { flowering }\end{array}$ & $\begin{array}{c}\text { No. of days to } \\
\text { maturity }\end{array}$ \\
\hline$T_{1}$ & KR-01 & 27.533 & 68.00 & 98.00 \\
\hline $\mathbf{T}_{2}$ & KR-02 & 26.333 & 64.66 & 99.33 \\
\hline $\mathbf{T}_{3}$ & KR-03 & 24.567 & 67.33 & 98.00 \\
\hline $\mathbf{T}_{4}$ & KR-04 & 26.200 & 71.33 & 102.0 \\
\hline $\mathbf{T}_{5}$ & KR-05 & 26.567 & 69.33 & 97.00 \\
\hline$T_{6}$ & KR-06 & 26.967 & 54.33 & 101.0 \\
\hline $\mathbf{T}_{7}$ & KR-07 & 25.467 & 75.00 & 98.66 \\
\hline $\mathbf{T}_{8}$ & KR-08 & 27.333 & 70.00 & 96.66 \\
\hline$T_{9}$ & KR-09 & 24.867 & 86.33 & 104.66 \\
\hline$T_{10}$ & KR-10 & 27.433 & 61.00 & 98.66 \\
\hline$T_{11}$ & KR-11 & 27.533 & 56.66 & 98.33 \\
\hline$T_{12}$ & KR-12 & 27.000 & 58.66 & 103.00 \\
\hline$T_{13}$ & KR-13 & 27.533 & 58.66 & 68.67 \\
\hline$T_{14}$ & KR-14 & 30.167 & 55.66 & 97.33 \\
\hline$T_{15}$ & KR-15 & 28.367 & 76.33 & 108.67 \\
\hline$T_{16}$ & KR-16 & 28.400 & 67.33 & 97.67 \\
\hline$T_{17}$ & KR-17 & 27.667 & 85.66 & 116.33 \\
\hline$T_{18}$ & KR-18 & 26.133 & 87.66 & 108.33 \\
\hline$T_{19}$ & KR-19 & 29.033 & 66.33 & 98.67 \\
\hline$T_{20}$ & KR-20 & 27.033 & 65.00 & 95.67 \\
\hline$T_{21}$ & KR-21 & 28.333 & 78.00 & 107.00 \\
\hline$T_{22}$ & KR-22 & 26.933 & 66.66 & 98.00 \\
\hline$T_{23}$ & KR-23 & 27.400 & 67.66 & 99.67 \\
\hline $\mathbf{T}_{24}$ & KR-24 & 26.133 & 68.33 & 102.00 \\
\hline $\mathbf{T}_{25}$ & KR-25 & 24.733 & 66.00 & 96.33 \\
\hline$T_{26}$ & KR-26 & 27.900 & 70.33 & 100.67 \\
\hline $\mathbf{T}_{27}$ & KR-27 & 27.867 & 60.00 & 98.67 \\
\hline $\mathbf{T}_{28}$ & KR-28 & 25.533 & 62.00 & 93.00 \\
\hline$T_{29}$ & KR-29 & 28.000 & 64.33 & 94.00 \\
\hline $\mathbf{T}_{30}$ & KR-30 & 26.400 & 67.00 & 96.33 \\
\hline$T_{31}$ & KR-31 & 26.533 & 66.66 & 105.67 \\
\hline$T_{32}$ & KR-32 & 28.200 & 66.66 & 100.00 \\
\hline $\mathbf{T}_{33}$ & KR-33 & 27.467 & 69.33 & 97.33 \\
\hline $\mathbf{T}_{34}$ & KR-34 & 24.667 & 62.66 & 96.33 \\
\hline$T_{35}$ & KR-35 & 26.600 & 65.66 & 97.33 \\
\hline$T_{36}$ & KR-36 & 27.600 & 70.00 & 102.00 \\
\hline$T_{37}$ & KR-37 & 26.800 & 68.00 & 102.33 \\
\hline$T_{38}$ & KR-38 & 30.700 & 70.00 & 98.00 \\
\hline$T_{39}$ & KR-39 & 28.000 & 67.66 & 101.67 \\
\hline$T_{40}$ & KR-40 & 28.767 & 77.00 & 105.33 \\
\hline \multicolumn{2}{|r|}{ F-test } & $\mathbf{S}$ & $\mathbf{S}$ & $\mathbf{S}$ \\
\hline \multicolumn{2}{|r|}{ S.Ed (+) } & 1.107 & 0.52 & 6.91 \\
\hline \multicolumn{2}{|r|}{ C.D. $(P=0.05)$} & 2.285 & 1.04 & 13.78 \\
\hline
\end{tabular}


Table.3 Performance of Hybrid Rice (Oryza Sativa L.) on Yield Attributes viz, No. of filled Grains panicle $^{-1}$, No. of un-filled Grains panicle ${ }^{-1}$, Grain yield plant ${ }^{-1}(\mathrm{~kg})$ and Grain yield (t ha $\left.{ }^{1}\right)$.

\begin{tabular}{|c|c|c|c|c|c|}
\hline & $\begin{array}{c}\text { Treatments Details } \\
\text { (Hybrids) }\end{array}$ & $\begin{array}{l}\text { No. of filled } \\
\text { Grains plant }^{-1}\end{array}$ & $\begin{array}{l}\text { No. of un-filled } \\
\text { Grains plant }^{-1}\end{array}$ & $\begin{array}{l}\text { Grain yield } \\
\text { plant }^{-1}(\mathrm{~g})\end{array}$ & $\begin{array}{c}\text { Grain yield } \\
\left(t \text { ha }^{-1}\right)\end{array}$ \\
\hline $\mathbf{T}_{1}$ & KR-01 & 227.66 & 27.33 & 25 & 10.02 \\
\hline $\mathbf{T}_{2}$ & KR-02 & 200.00 & 47.11 & 26 & 9.130 \\
\hline $\mathbf{T}_{3}$ & KR-03 & 194.66 & 39.66 & 34 & 7.947 \\
\hline $\mathbf{T}_{4}$ & KR-04 & 206.66 & 23.66 & 23 & 7.333 \\
\hline $\mathbf{T}_{5}$ & KR-05 & 208.66 & 50.33 & 36 & 8.180 \\
\hline $\mathbf{T}_{6}$ & KR-06 & 269.66 & 40.00 & 25 & 8.737 \\
\hline $\mathbf{T}_{7}$ & KR-07 & 237.33 & 37.33 & 24 & 9.113 \\
\hline $\mathbf{T}_{8}$ & KR-08 & 194.66 & 37.66 & 24 & 8.503 \\
\hline $\mathbf{T}_{9}$ & KR-09 & 234.66 & 42.66 & 24 & 9.400 \\
\hline$T_{10}$ & KR-10 & 192.00 & 23.33 & 24 & 6.667 \\
\hline$T_{11}$ & KR-11 & 260.66 & 31.00 & 26 & 6.397 \\
\hline $\mathbf{T}_{12}$ & KR-12 & 189.00 & 24.33 & 23 & 6.873 \\
\hline $\mathbf{T}_{13}$ & KR-13 & 237.00 & 33.66 & 29 & 10.12 \\
\hline $\mathbf{T}_{14}$ & KR-14 & 199.66 & 45.66 & 27 & 9.293 \\
\hline$T_{15}$ & KR-15 & 213.00 & 64.66 & 26 & 9.147 \\
\hline$T_{16}$ & KR-16 & 244.33 & 85.66 & 30 & 10.52 \\
\hline $\mathbf{T}_{17}$ & KR-17 & 219.33 & 31.66 & 24 & 8.360 \\
\hline$T_{18}$ & KR-18 & 198.66 & 47.33 & 22 & 9.883 \\
\hline$T_{19}$ & KR-19 & 214.33 & 25.66 & 24 & 9.470 \\
\hline $\mathbf{T}_{20}$ & KR-20 & 208.33 & 51.00 & 27 & 9.440 \\
\hline$T_{21}$ & KR-21 & 240.33 & 49.66 & 31 & 8.197 \\
\hline $\mathbf{T}_{22}$ & KR-22 & 215.00 & 43.33 & 26 & 9.187 \\
\hline $\mathbf{T}_{23}$ & KR-23 & 199.33 & 35.33 & 35 & 7.890 \\
\hline $\mathbf{T}_{24}$ & KR-24 & 208.66 & 57.30 & 34 & 9.897 \\
\hline $\mathbf{T}_{25}$ & KR-25 & 260.00 & 40.67 & 34 & 11.43 \\
\hline $\mathbf{T}_{26}$ & KR-26 & 221.33 & 37.33 & 34 & 8.850 \\
\hline $\mathbf{T}_{27}$ & KR-27 & 223.66 & 42.00 & 27 & 9.183 \\
\hline $\mathbf{T}_{28}$ & KR-28 & 235.00 & 31.00 & 24 & 7.227 \\
\hline $\mathbf{T}_{29}$ & KR-29 & 258.33 & 34.33 & 36 & 10.82 \\
\hline $\mathbf{T}_{30}$ & KR-30 & 237.66 & 38.33 & 30 & 10.29 \\
\hline $\mathbf{T}_{31}$ & KR-31 & 243.33 & 32.33 & 34 & 10.67 \\
\hline$T_{32}$ & KR-32 & 193.33 & 37.00 & 25 & 8.177 \\
\hline$T_{33}$ & KR-33 & 261.33 & 48.33 & 34 & 10.06 \\
\hline $\mathbf{T}_{34}$ & KR-34 & 204.66 & 33.33 & 26 & 10.16 \\
\hline $\mathbf{T}_{35}$ & KR-35 & 252.66 & 40.00 & 40 & 11.96 \\
\hline $\mathbf{T}_{36}$ & KR-36 & 254.33 & 39.33 & 31 & 10.77 \\
\hline $\mathbf{T}_{37}$ & KR-37 & 248.66 & 45.00 & 29 & 9.183 \\
\hline $\mathbf{T}_{38}$ & KR-38 & 307.66 & 22.56 & 41 & 13.96 \\
\hline$T_{39}$ & KR-39 & 216.66 & 39.33 & 34 & 7.743 \\
\hline $\mathbf{T}_{40}$ & KR-40 & 257.66 & 43.00 & 25 & 9.250 \\
\hline \multicolumn{2}{|r|}{ F-test } & $\mathbf{S}$ & $\mathbf{S}$ & $\mathbf{S}$ & $\mathbf{S}$ \\
\hline \multicolumn{2}{|r|}{ S.Ed (+) } & 23.861 & 4.46 & 2.0 & 1.05 \\
\hline \multicolumn{2}{|r|}{ C.D. $(P=0.05)$} & 47.596 & 8.91 & 5.0 & 2.09 \\
\hline
\end{tabular}


Table.4 Performance of Hybrid Rice Cultivar (Oryza Sativa L.) on Yield Attributes viz, Test weight (g) and Grain Type (Shape)

\begin{tabular}{|c|c|c|c|}
\hline & $\begin{array}{c}\text { Treatments Details } \\
\text { (Hybrids) }\end{array}$ & Test weight (g) & Grain type (Shape) \\
\hline $\mathbf{T}_{1}$ & KR-01 & 25.35 & Long Slender \\
\hline $\mathbf{T}_{2}$ & KR-02 & 23.64 & Long Slender \\
\hline $\mathbf{T}_{3}$ & KR-03 & 25.79 & Long Slender \\
\hline $\mathbf{T}_{4}$ & KR-04 & 26.12 & Long Slender \\
\hline $\mathbf{T}_{5}$ & KR-05 & 22.74 & Long Slender \\
\hline$T_{6}$ & KR-06 & 22.04 & Long Slender \\
\hline $\mathbf{T}_{7}$ & KR-07 & 24.14 & Long Slender \\
\hline $\mathbf{T}_{8}$ & KR-08 & 21.53 & Long Slender \\
\hline $\mathbf{T}_{9}$ & KR-09 & 23.54 & Medium Slender \\
\hline$T_{10}$ & KR-10 & 21.36 & Medium Slender \\
\hline$T_{11}$ & KR-11 & 26.78 & Long Slender \\
\hline $\mathbf{T}_{12}$ & KR-12 & 21.34 & Medium Slender \\
\hline $\mathbf{T}_{13}$ & KR-13 & 24.47 & Long Slender \\
\hline$T_{14}$ & KR-14 & 26.54 & Medium Slender \\
\hline$T_{15}$ & KR-15 & 24.26 & Medium Slender \\
\hline$T_{16}$ & KR-16 & 20.24 & Medium Slender \\
\hline $\mathbf{T}_{17}$ & KR-17 & 27.32 & Long Slender \\
\hline $\mathbf{T}_{18}$ & KR-18 & 23.29 & Medium Slender \\
\hline$T_{19}$ & KR-19 & 20.46 & Long Slender \\
\hline $\mathbf{T}_{20}$ & KR-20 & 21.72 & Long Slender \\
\hline $\mathbf{T}_{21}$ & KR-21 & 29.79 & Medium Slender \\
\hline $\mathbf{T}_{22}$ & KR-22 & 24.23 & Long Slender \\
\hline $\mathbf{T}_{23}$ & KR-23 & 20.88 & Medium Slender \\
\hline $\mathbf{T}_{24}$ & KR-24 & 23.45 & Medium Slender \\
\hline $\mathbf{T}_{25}$ & KR-25 & 27.42 & Long Slender \\
\hline $\mathbf{T}_{26}$ & KR-26 & 24.22 & Long Slender \\
\hline $\mathbf{T}_{27}$ & KR-27 & 22.72 & Long Slender \\
\hline $\mathbf{T}_{28}$ & KR-28 & 21.03 & Medium Slender \\
\hline $\mathbf{T}_{29}$ & KR-29 & 21.12 & Medium Slender \\
\hline $\mathbf{T}_{\mathbf{3 0}}$ & KR-30 & 23.23 & Long Slender \\
\hline $\mathbf{T}_{31}$ & KR-31 & 27.64 & Medium Slender \\
\hline $\mathbf{T}_{32}$ & KR-32 & 24.32 & Long Slender \\
\hline $\mathbf{T}_{33}$ & KR-33 & 27.37 & Long Slender \\
\hline $\mathbf{T}_{34}$ & KR-34 & 23.32 & Long Slender \\
\hline $\mathbf{T}_{35}$ & KR-35 & 24.88 & Long Slender \\
\hline $\mathbf{T}_{36}$ & KR-36 & 22.23 & Long Slender \\
\hline $\mathbf{T}_{37}$ & KR-37 & 23.83 & Long Slender \\
\hline $\mathbf{T}_{38}$ & KR-38 & 29.89 & Long Slender \\
\hline $\mathbf{T}_{39}$ & KR-39 & 21.24 & Medium Slender \\
\hline $\mathbf{T}_{40}$ & KR-40 & 22.12 & Long Slender \\
\hline \multicolumn{2}{|r|}{ F-test } & - & -- \\
\hline \multicolumn{2}{|r|}{ S.Ed (+) } & - & -- \\
\hline \multicolumn{2}{|r|}{ C.D. $(P=0.05)$} & - & -- \\
\hline
\end{tabular}


Fig.1Performance of Hybrid Rice Cultivar (Oryza Sativa L.) on Growth Attributes viz, Germination (\%), Plant height (cm), Number of tiller per $\mathrm{m}^{2}$ and Number of tiller hill ${ }^{-1}$.

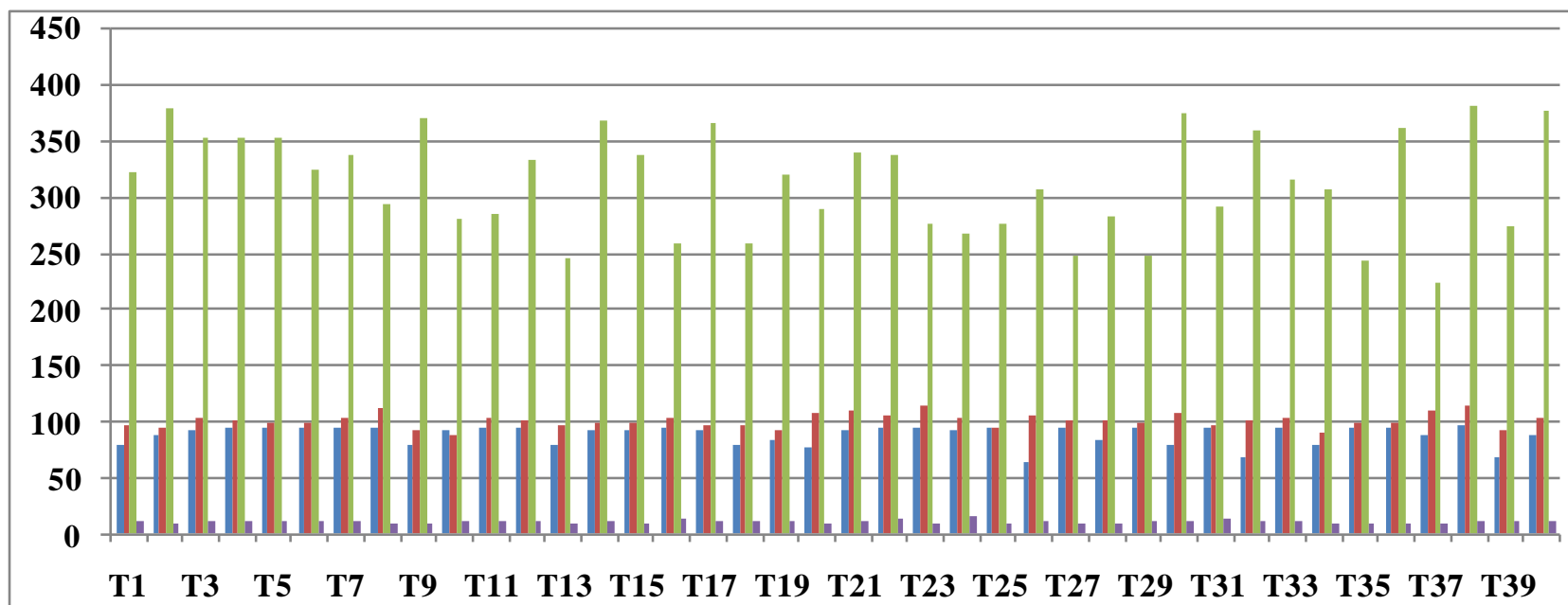

Germination \% (in laboratory)

Plant height $(\mathrm{cm})$

No. of tiller per $\mathbf{m} 2$

No. of tiller per hill

Fig.2 Performance of Hybrid Rice Cultivar (Oryza Sativa L.) on Growth Attributes viz, Panicle length (cm), Day to 50 (\%) flowering and No. of days to maturity

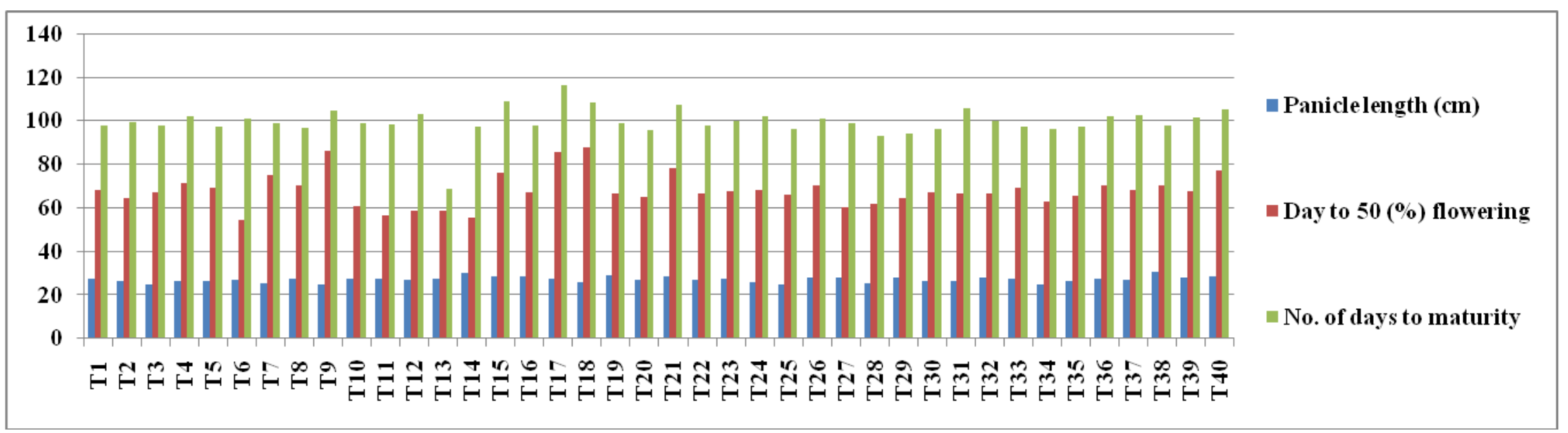


Fig.3 Performance of Hybrid Rice Cultivar (Oryza Sativa L.) on Yield Attributes viz, No. of filled Grains panicle ${ }^{-1}$, No. of un-filled Grains panicle $^{-1}$, Grain yield plant ${ }^{-1}(\mathrm{~kg})$, Grain yield $\left(\mathrm{t} \mathrm{ha}^{-1}\right)$ and Test weight $(\mathrm{g})$.

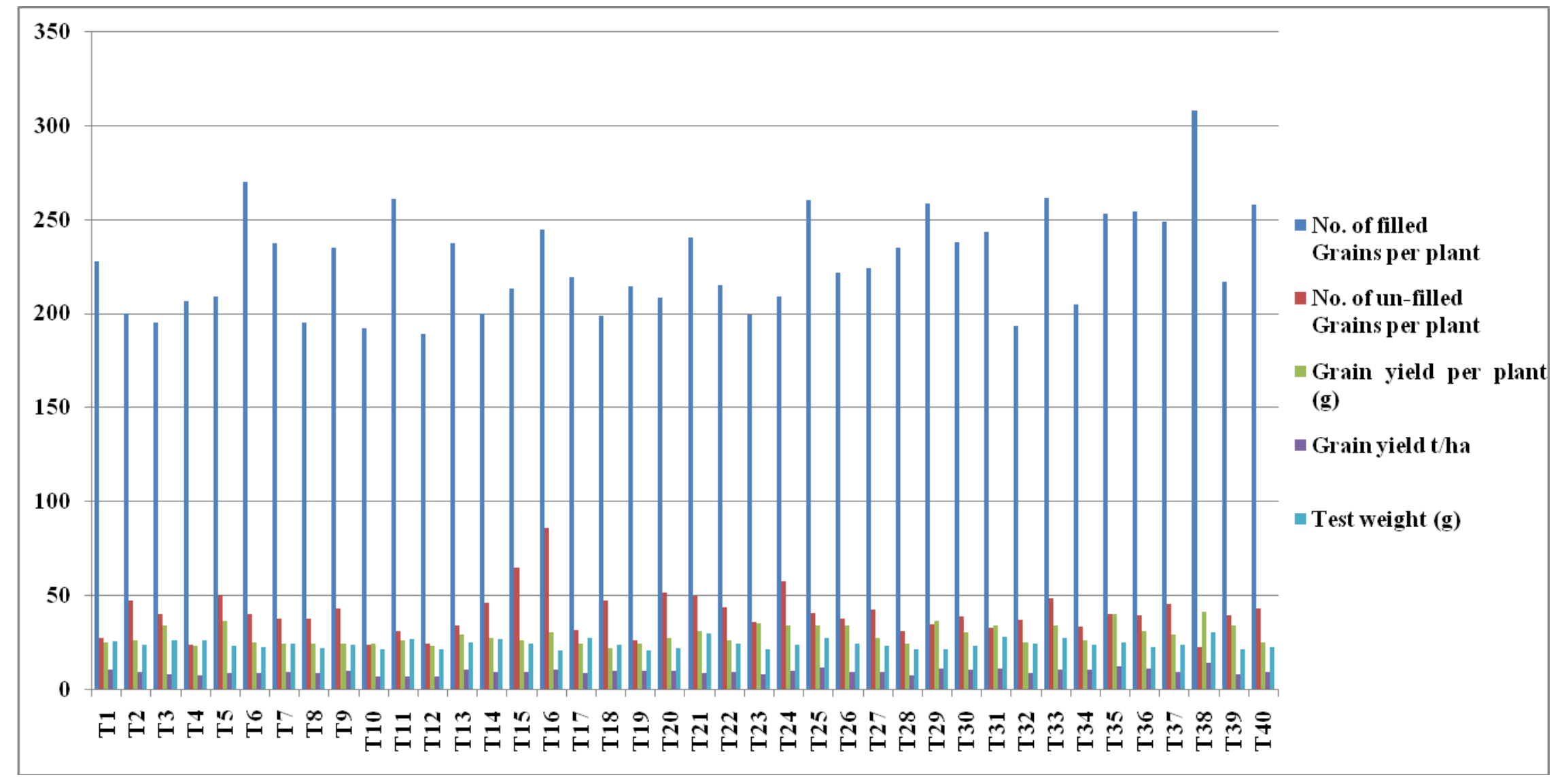




\section{Grain yield $\left(\mathrm{t} \mathrm{ha}^{-1}\right)$}

Highest grain yield $\left(13.96 \mathrm{t} \mathrm{ha}^{-1}\right)$ was observed in treatment $\mathrm{T}_{38}$ (KR 38) followed by (11.96 and $11.43 \mathrm{t} \mathrm{ha}^{-1}$ ) in Treatment $\mathrm{T}_{35}$ (KR 35) and $\mathrm{T}_{25}$ (KR 25). While lowest grain $\left(6.39 \mathrm{t} \mathrm{ha}^{-1}\right)$ was observed in Treatment $\mathrm{T}_{11}(\mathrm{KR} 11)$ as shown in (Table 3) and (Fig 3) respectively.

\section{Test weight (g) and Grain Shape}

Highest test weight (29.89 g) and grain shape (Long Slender) was recorded in treatment $\mathrm{T}_{38}$ (KR 38), while lowest test weight (20.24 g) and grain shape (Medium Slender) was recorded in treatment $\mathrm{T}_{16}(\mathrm{KR} 16)$ as shown in (Table 4) and (Fig 3) respectively. The yield attributes are significantly influenced by genetic potential of the plant attributed to higher biomass accumulation coupled with effective translocation and distribution of photosynthates from source to sink, which in turn resulted into elevated stature of yield attributes, which of course was due to favourable weather conditions such as rainfall distribution, evaporation and relative humidity prevailed during the crop growth period. This result also may be due to synchronized availability of essential plants nutrients to the crop especially NPK for a longer period during its growth \& reproductive stages. In several hybrid rice cultivars, the effect on number of effective tillers, longer panicles, more spikelets panicle ${ }^{-1}$, number of filled grains plant ${ }^{-1}$, number of un-filled grains plant ${ }^{-}$ 1, Grain yield plant ${ }^{-1}$, Grain yield $\left(\mathrm{t} \mathrm{ha}{ }^{-1}\right)$, Stover yield $\left(\mathrm{t} \mathrm{ha}^{-1}\right)$, Test weight $(\mathrm{g})$ and Grain Shape was observed significant. Some findings of the experiment conducted by researchers concluded that the reason for better yield attributes was reported by Ranjitha et al., 2013. According to Gulzar et al., 2012 the grains panicle $\mathrm{e}^{-1}$ of had maximum positive correlation coefficient with grain yield. According to Neelam et al., 2009 hybrid rice have longer panicles and more spikelets panicle $^{-1}$ and thus in the study had significantly produced the longest panicle among the hybrid experiment.

In conclusion, from the data pertaining to the different treatments, it may be concluded that by using hybrid KR 38 (KR 38) higher yield and monetary benefits can be realized over local cultivars. Hybrid KR 38 (KR 38) was found to be the best for obtaining highest seed yield, stover yield, gross return, net return and benefit cost ratio. Since the findings are based on the research done in one season it may be repeated for further confirmation.

\section{Acknowledgements}

The author acknowledges the department of Agronomy, Allahabad School of Agricultural, Sam Higginbottom University of Agriculture Technology \& Sciences, Allahabad (Uttar Pradesh) for providing financial support to carry out the research work.

\section{References}

Akram, M., Rehman, A., Ahmad, M. and Cheema, A. A. (2007). Evaluation of rice (Oryza sativa L.) hybrids for yield and yield components in three different environments. J.Anim. Pl. Sci. 17 :(3-4).

Anonymous (2005). The Hindu Survey of Indian Agriculture. pp. 41- 46.

Anonymous (2006). The Hindu Survey of Indian Agriculture. pp. 50-54.

Bouman, B.A.M (2009). How much water does rice use? Rice Today, 8 (1): 28-29.

Carriger, S. and Vallee, D. (2007). More crop per drop. Rice Today. 6:10-13.

Deshpande, H.H., and Devasenapathy, P. (2011). Effect of green manuring and organic manures on yield, quality and economics of rice (Oryza sativa L.) under lowland condition. Karnataka Journal of Agricultural Sciences 23 (2): 235-238.

FAO (2011). Directorate of economics and statistics: Ministry of Agriculture.

GOI (2017). Agricultural statistics at a glance: Ministry of Agriculture, Govt. of India. 
GOI (2019). Agricultural statistics at a glance: Ministry of Agriculture, Govt. of India.

Gulzar, S., Sanghera, Subhash and Kashyap, C. (2012). Genetic Parameters and Selection Indices in F3 Progenies of Hill Rice Genotypes. Not Sci Biol, 4 (4):110-114.

Haque MD., Elora Pervin and MD., Romel Biswash (2015). Identification of Potential Hybrid Rice Variety in Bangladesh by Evaluating the Yield Potential World Journal of Agricultural Sciences 11(1): 13-18.

Kalyani, D. Lakshmi (2012). Performance of clusterbean (Cymopsis tetragonoloba L.) genotypes under varied time of sowing. Legume Res., 35 (2): 154-158.

Kumar, Manoj, Patel, H.K., Patel, C.N., Umale, A.A. and Patel, J.J. (2015) Varietal response of summer clusterbean (Cymopsis tetragonoloba L.) to different irrigation scheduling (IW: CPE ratios) under middle Gujarat conditions, Eco. Env. \& Cons: S159S163.

Mohanty, S. (2013). Trends in Global Rice Consumption. Rice Today. IRRI, pp. 44-45.

Neelam, Sandhyakishore, M.S. Ramesha, T. Dayakar Reddy and A. Siva Sankar. (2009). Study of heterosis by utilizing male sterility restoration system in rice (Oryza sativa L.) Journal of Rice Research. 2: (2) 93-98.

Paramasivan, K.S. and Rangaswamy, S.R.S. (1988). Genetic analysis of yield and its components in rice. Oryza 25: 111-119.

Parihar, C. M., Kaushik, M. K. and Palsaniya, D. R. (2005). Effect of varieties, plant density and phosphorus levels on growth and yield of clusterbean (Cyamopsis tetragonoloba. L.), Annals of Agril. Res. 26 (1): 5-7.

PhilRice (2002). Hybrid Rice. "Q \& A" Series, PhilRice Maligaya, Muñoz, Nueva Ecija. 1, 4-6.
Rahman M.M., Islam M.T., Faruq A.N., Akhtar N., Ora N. and Uddin M.M. (2013). Evaluation of Some Cultivated Hybrid Boro Rice Varieties against BLB, ShB and ALS Diseases under Natural Epiphytic Conditions Middle East Journal of Scientific Research 15 (1): 146-151.

Ranjitha, Sri. R., Kumar, Mahender and Jayasree, G. (2013). Evaluation of rice (Oryza sativa L.) varieties and hybrids in relation to different nutrient management practices for yield, nutrient uptake and economics in SRI Annals of Biological Research, 4 (10):25-28.

Sharma, R., Gangwar, R.K., Yadav, V. and Kumar, R. (2014). Response of Basmati rice (Oryza sativa) cultivars to graded Nitrogen levels under transplanted condition. International Journal of Research in Applied, Natural and Social Sciences Vol. 2 (9): 3338.

Singh, R. and Khan, M. A. (2003). Response of clusterbean (Cyamopsis tetragonoloba L.) varieties to fertility levels and cropping systems under arid condition. Advances in arid legume research. 225-228.

Stoop, W.A., Adam, A and Kassam, A., (2009). Comparing rice production systems: A challenge for agronomic research and for the dissemination of knowledge-intensive farming practices. Agricultural Water Management. 96:1491-1501.

Yadav S K, Suresh B G, Pandey Praveen, Kumar Binod (2010). Assessment of genetic variability, correlation and path association in rice (oryza sativa L.) Journal of bioscience, 18:1-8.

Yadav, Priyanka, Rangare, N. R., John, P. Anurag and Chaurasia, A. K. (2004). Quantitative analysis of rice (Oryza sativa L.) in Allahabad agro climate zone. Journal of Rice Research 3(1):1-6.

\section{How to cite this article:}

Vikram Singh, Rachana, Prasad Mithare, Sujit Kumar, J. P. Mishra, Sachchida Nand Singh, Dhananjay Tiwari and Lalit Kumar Sanodiya 2019. Performance of Hybrid Rice Cultivar (Oryza sativa L.) on Growth and Yield Attributes under Agro-Climatic Conditions of Allahabad Uttar Pradesh in Aman Season of Planting. Int.J.Curr.Microbiol.App.Sci. 8(09): 2970-2982. doi: https://doi.org/10.20546/ijcmas.2019.809.341 